\title{
De betekenis voor beleid en theorievorming van enige recente ontwikkelingen in de econometrie
}

Citation for published version (APA):

Palm, F. C. (1978). De betekenis voor beleid en theorievorming van enige recente ontwikkelingen in de econometrie. Vrije Universiteit. https://doi.org/10.26481/spe.19780421fp

Document status and date:

Published: 21/04/1978

DOI:

10.26481/spe.19780421fp

Document Version:

Publisher's PDF, also known as Version of record

\section{Please check the document version of this publication:}

- A submitted manuscript is the version of the article upon submission and before peer-review. There can be important differences between the submitted version and the official published version of record.

People interested in the research are advised to contact the author for the final version of the publication, or visit the DOI to the publisher's website.

- The final author version and the galley proof are versions of the publication after peer review.

- The final published version features the final layout of the paper including the volume, issue and page numbers.

Link to publication

\footnotetext{
General rights rights.

- You may freely distribute the URL identifying the publication in the public portal. please follow below link for the End User Agreement:

www.umlib.nl/taverne-license

Take down policy

If you believe that this document breaches copyright please contact us at:

repository@maastrichtuniversity.nl

providing details and we will investigate your claim.
}

Copyright and moral rights for the publications made accessible in the public portal are retained by the authors and/or other copyright owners and it is a condition of accessing publications that users recognise and abide by the legal requirements associated with these

- Users may download and print one copy of any publication from the public portal for the purpose of private study or research.

- You may not further distribute the material or use it for any profit-making activity or commercial gain

If the publication is distributed under the terms of Article $25 \mathrm{fa}$ of the Dutch Copyright Act, indicated by the "Taverne" license above, 
De betekenis voor beleid en theorievorming van enige recente ontwikkelingen in de econometrie

OPENBARE LES gegeven bij de aanvaarding van het ambt van lector in de wiskundige economie en econometrie aan de Faculteit der Economische Wetenschappen van de Vrije Universiteit te Amsterdam op vrijdag 21 april 1978.
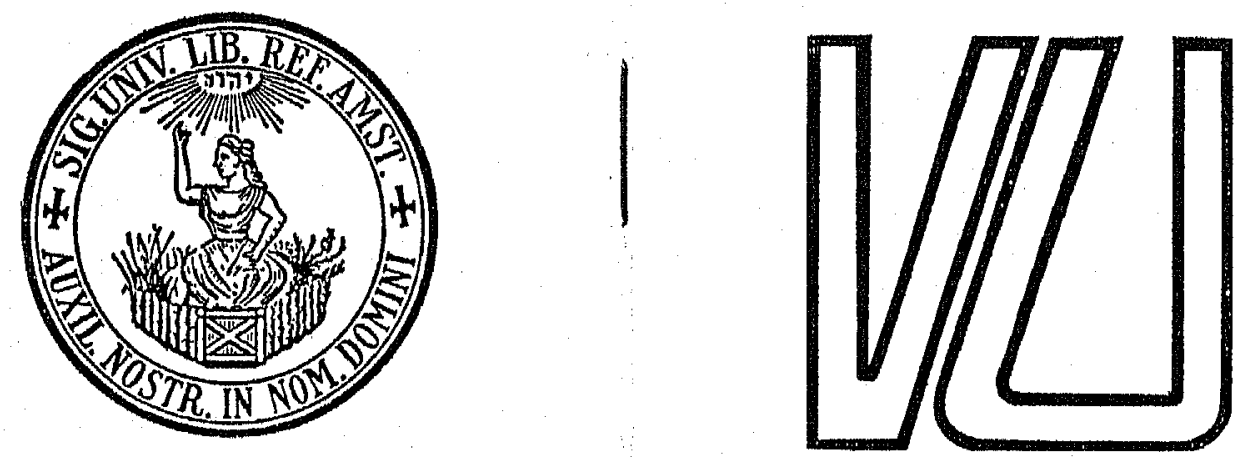
De betekenis

voor beleid en theorievorming van enige recente ontwikkelingen in de econometrie

OPENBARE LES gegeven bij de aanvaarding van het ambt van lector in de wiskundige economie en econometrie aan de Faculteit der Economische Wetenschappen van de Vrije Universiteit te Amsterdam op vrijclag 21 april 1978

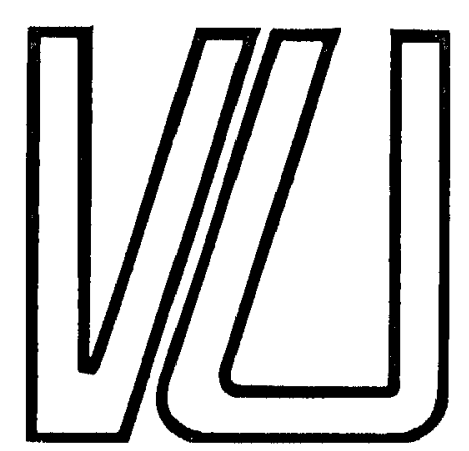


Mijnheer de Rector Magnificus,

Dames en Heren,

\section{Inleiding}

$\mathrm{Na}$ een periode van roemvolle ontwikkelingen in de econometrie en de wiskundige economie, die bijna veertig jaar geleden door J. Tinbergen werd ingeleid met zijn boek „Statistical Testing of Business Cycle Theories", is men tegenwoordig skeptischer geworden ten aanzien van de resultaten van de kwantitatieve benadering in de economische wetenschap. De eerste fase in de ontwikkeling van de kwantitatieve methoden in de economie droeg het kenmerk van optimisme omtrent de mogelijkheden van deze nieuwe hulpmiddelen. Tegenwoordig worden wiskundige en statistische technieken meer en meer toegepast bij de analyse en oplossing van economische problemen. De overvloed van formules in economieboeken en tijdschriften legt getuigenis af van de voorkeur voor kwantitatieve methoden bij de huidige economen. Toch blijkt aan de andere kant dat de wiskundige benadering van economische problemen aan de misschien te hoog gestelde verwachtingen niet kan voldoen. De teleurstelling over het gebrek aan voorspelkracht van bestaande modellen is een openbaar geheim. Werd de Nobelprijs in de economie in de eerste jaren vooral toegekend aan wiskundige economen, in de laatste twee jaren daarentegen zijn studies op het gebied van de monetaire theorie en van de internationale handel geëerd.

Zouden we dan moeten concluderen dat het vertrouwen in de mogelijkheden van de kwantitatieve methoden in de economische wetenschap daalt naarmate de problemen in de westerse economieën toenemen? Zou de econometrist nu een misschien trieste voorspelling moeten doen? Naar mijn mening kan hij niet tevreden zijn met een schijncorrelatic. Hij moet immers de causale samenhang ontdekken. Hij moet zich afvragen, waarom de wiskundige economie en de econometrie dikwijls niet aan de verwachtingen voldoen.

Certa mittimus, dum incerta petimus.

(Plautus, Pseudolus, 685)

Deze openbare les biedt de gelegenheid de vraag te stellen naar de mogelijkheden en de vooruitzichten van het vakgebied, waarin ik onderwijs geef en onderzoek verricht. Graag wil ik U, waarde toehoorders, mijn gedachten hierover voorleggen en daarbij trachten het beeld, dat $U$ mogelijk van mijn vakgebied heeft, iets scherper te omlijnen. Zoals gebruikelijk in de econometrie zal ik inductief te werk gaan. In mijn verdere betoog wil ik de betekenis voor het economisch beleid en de theorievorming in de economische wetenschap, zoals die aan enige recente bijdragen tot de econometrie dudidelijk wordt, bespreken.

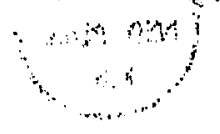




\section{De theorie van het economisch beleid herzien}

De economie wordt meestal gedefiniëerd als de wetenschap, die zich bezig houdt met het optimale besteden van schaarse middelen. Twee belangrijke aspecten aan een economisch probleem blijven in een dergelijke definitie echter op de achtergrond.

Het eerste aspect behelst het feit, dat bijna elke economische beslissing plaats heeft in het kader van wederkerige afhankelijkheid. Ze veroorzaakt reacties bij de tegenpartij. Stel dat er een bedrijf is, dat over een nieuw investeringsplan een besluit moet nemen. Door het scheppen van werkgelegenheid zouden arbeidskrachten kunnen worden aangetrokken. De beslissing van de onderneming kan voor de concurrenten een voorbeeld tot navolging worden. Vanaf de verschijning van het werk van Walras ${ }^{1}$ is de problematiek van de wederkerige afhankelijkheid in de economie veel bestudeerd, zowel in studies over de theorie van het algemene evenwicht als in de jongere bijdragen tot de theorie van onevenwich tsmodellen.

Een tweede aspect aan een economisch probleem is de onzekerheid aangaande de gevolgen van een economische beslissing. Niet geheel bekend is, hoe anderen gaan reageren, hoe de omstandigheden in de toekomst zullen zijn. Het genoemde bedrijf moet zich afvragen, hoe de afzet van zijn produkten zal evolueren. En welke prijsontwikkeling zal er zijn? Zullen de loonkosten stijgen?

Het is nu de taak van de wiskundige economie de belangrijkste aspecten aan een economisch probleem in een wiskundige vorm te gieten en wel door opstelling van een model. $\mathrm{Ze}$ is dus een specialisatie ${ }^{2}$ naar de methode en niet naar het te bestuderen verschijnsel. Andere methoden naast de wiskundige behouden natuurlijk hun volle waarde als hulpmiddelen in de economische wetenschap. Maar het voordeel van de wiskundige benadering ligt in de kwantificering van economische verschijnselen. Dit betekent uiteraard niet dat kwalitatieve aspecten uitgesloten moeten worden geacht, zoals Prof. P. Kirschenmann ${ }^{3}$ onlangs ook in zijn inaugurele oratie vaststelde. Daarna worden in de econometrie vooral de statistische aspecten van deze modellen behandeld, bijv. het schatten van de modelparameters, het toetsen van hypothesen. De term "model" wordt hier gebruikt in de nauwe betekenis van een stelsel van vergelijkingen, van een beschrijving in wiskundige vorm van het gedrag van consumenten, producenten en overheid. Bij de opstelling van een model wordt meestal beoogd dat het model de beste voorspelling zal dienen te leveren of het beste beleid zal moeten aantonen, althans voor zover mogelijk. Gelet op de moeilijkheden, die bij een economische beslissing bij onzekerheid in het kader van wederkerige afhankelijkheid kunnen optreden, moeten de aan een model te stellen eisen hoog zijn.

Veronderstel nu dat er een overheidsinstelling is, die een econometrisch model construeert ter ondersteuning van het beleid. De modelbouwers specificeren het model ten einde de huidige omstandigheden te verklaren. Uitgaande van statistische gegevens uit het verleden worden de modelparameters geschat. Misschien wordt dan het model op grond van de ongewenste schattingsresultaten of de uitkomsten van de statistische toetsen veranderd. Het gewijzigde model wordt dan op nieuw geschat. Voor het gebruik van het model wordt meestal een doelstellingsfunctie gespecificeerd, die een waardering van bepaalde politieke doeleinden weergeeft. Daarbij wordt ook rekening gehouden met de kosten bij het uitvoeren van het beleid. Ook mogelijke restricties op de doeleinden en instrumentvariabelen worden ingebracht. Daarna wordt getracht dat beleid te vinden, dat aan de doelstellingsfunctie de hoogst mogelijke waarde geeft. Is het doel de werkloosheidsbestrijding, dan kan de overheid werkgelegenheid scheppen door additionele uitgaven - binnen bepaalde grenzen. Het doel kan ook worden bereikt door een wisselkoersverandering, waardoor de goederenuitvoer gestimuleerd wordt en de invoergoederen duurder gemaakt worden. In principe is het beleidsprobleem oplosbaar met behulp van programmeringstechnieken, mits de doelstellingsfunctie, het model en de voorwaarden voor de doeleinden en de instrumentvariabelen gespecificeerd zijn.

We hebben tot nu toe een beschrijving van de praktijk gegeven, zoals die bijna vijftien jaar geleden in Theil's boek ${ }^{4}$,Optimal Decision Rules for Government and Industry" werd geformuleerd. Elk model is maar een benadering van de werkelijkheid. De variatie bij de endogene variabelen, die niet zonder meer verklaarbaar is, kan ondervangen worden door de invoering van een storingsterm. Onzekerheid treedt daarnaast $o p$ in de onbekende parameterstructuur.

De gangbare modellen hebben als basis de interactie tussen beslissingen van de verschillende partijen in de economische samenleving. Het is in de mode grote modellen op te stellen, dikwijls met enkele honderden vergelijkingen. Het model van de Brookings Institution werd destijds als navolgenswaardig voorbeeld beschouwd. Getracht wordt de algemene afhankelijkheid in de economie van een staat, ja zelfs in de wereldeconomie, met behulp van modellen te verklaren. Hoewel meestal de algemene afhankelijkheidsproblematiek bij het statistische schatten van de parameters in het model verwaarloosd wordt, wordt toch het volledige model bij de simulatie van alternatieve beleidsvormen gebruikt. De algemene wederkerige afhankelijkheid en interactie in het economische leven staat tegenwoordig centraal in de economische theorie en de econometrie. Fundamentele bijdragen erover zijn door Nederlanders geleverd. Aan Tinbergen's vaststelling ${ }^{5}$,It has taken a considerably long time before even economists looked at economic policy as a 'coherent entity'." blijft toe te voegen dat het nog langer heeft geduurd, voordat economen de economische politiek als een beslissing in een 
wereld van onzekerheid zijn gaan analyseren.

Een van de volgens mij belangrijkste recente ontwikkelingen in de econometrie leidt tot een herziening van - zoals de Amerikaanse auteur Lucas ${ }^{\prime}$ het noemde - „Tinbergen's Theory of Economic Policy". We worden elke dag met economische beslissingen geconfrontecrd die we, doordat we onvolledig worden geïnformeerd over de gevolgen ervan, voor lief zullen moeten nemen. Natuurlijk komt er ook elke dag nieuwe informatie beschikbar. We lezen in de krant over de gebeurtenissen in de politiek, over internationale overeenkomsten, over de ontwikkelingen op de arbeidsmarkt en de beursnoteringen. Deze nieuwe informatie beïnvloedt het afwegen van de toekomstige ontwikkeling en aldus de besluitvorming. In de econometrische modellen wordt verondersteld dat deze informatie de waarde van de verwachtingsvariabe len bepaalt. Bij investeringen speelt de verwachte opbrengst een belangrijke rol. De consumptie-uitgaven worden naast andere variabelen ook beinvloed door de verwachte inkomensstroom. Het is bijna een traditie geworden in de econometrische modelbouw om de verwachtingswaarde van een variabele door haar eigen historische waarden te verklaren. Verondersteld wordt bijv. dat de verwachte inflatievoet cen gewogen som van de prijsontwikkeling in het verleden is. De verdeelde vertragingen in de econometrie - men clenke aan de fundamentele bijclage van de Nederlander Koyck ${ }^{7}$ - vinden hierin een theoretische rechtvaardiging.

$\mathrm{Nu}$ is het gebruikelijk te veronderstellen dat het economisch gedrag bij onzekerheid rationeel is. Deze term vereist wellicht uitleg. Voor elke beslissing staan informatie, gegevens, crvaring, dikwijls cen econometrisch model ter beschikking. Rationeel gedrag in een wereld van on zekerheid impliceert dat de nieuwe informatie bij jedere beslissing onmiddellijk in beschouwing wordt genomen. Als op elk tijdstip de verwachtingsvariabelen in een model de op grond van de beschikbare informatie verwachte waarde van de variabelen zelf voorstellen, dan spreken we over rationele verwachtingen. Deze zijn in principe afhankelijk van alle gepredetermineerde variabelen in het model. In de statistische terminologie betekent dit dat de verwachtingen, gelet op de beschikbare informatie, optimale voorspellingen voorstellen. (De term „verwachtingen" wordt hier gebruikt in de statistische betckenis en niet in de door Keynes in zijn "General Theory" gehanteerde psychologische betekenis.) Al een aantal jaren wordt de theorie van rationeel gedrag bij onzekerheid in de beleggingsleer onder de titel theorie van de efficiënte markt besproken en getoetst. De bedrijfseconomen zijn vertrouwd met deze aanpak, die ik straks nog aan de orde zal stellen.

In de econometrie werden de rationele verwachtingen ingevoerd met de bijdragen van Muth in 1960 en $196 \mathrm{I}^{\mathrm{B}}$, maar de basis voor dit begrip was al gelegd in de besliskunde bij onzekerheid, zoals ontworpen door
L. J. Savage (1954) en verder ontwikkeld in de theorie van het algemene evenwicht bij onzekerheid door K. J. Arrow (1953)10, G. Debreu (1959) ${ }^{11}$ en anderen. Hoewel de besliskunde bij onzekerheid een belangrijk onderzoeksgebied is, is in de econometrie en vooral in de modelbouw weinig aandacht geschonken aan de erin bereikte conclusies, vooral omdat deze tot zeer abstracte modellen zouden leiden. Tot voor kort bestond de praktijk in specificatie ad hoc van vergelijkingen voor de verwachtingsvariabelen. Sinds de publicatie in 1976 van Lucas' studie, die overigens al eerder in de V.S. ter discussie had gestaan, wordt veel gewicht gehecht aan de veronderstelling van rationeel gedrag bij onzekerheid en de gevolgen ervan voor de beleidstheorie.

Laat ik het artikel van Lucas kort samenvatten. Hij zegt erin dat hij een econometrisch model wil gebruiken om de gevolgen van verschillende beleidsmogelijkheden te vergelijken. Zodra een beleid kenbaar wordt gemaakt of alleen maar aangeduid, bijv. door de politieke kleur van een regeringscoalitie, dan worden de verwachtingen erdoor beïnvloed en zo ook het gedrag van de verschillende groepen in de economie. Kortom, „Van programma's naar prognoses” is het devies ${ }^{12}$. In een model met rationele verwachtingen leidt een beleidswijziging tot een verandering van de parameterwaarden en dus tot een verandering van het model zelf. Willen we de gevolgen van verschillende beleidsvoorstellen beoordelen, dan moeten we eerst rekening houden met de gedragsveranderingen en de hieruit voortvloeiende modelverandering, voordat we de gevolgen van iedere beleidslijn in cijfers kunnen uitdrukken. De implicaties van Lucas' studie voor theorie en praktijk van de economische politiek zijn aanzienlijk, indien althans de veronderstelling van rationele verwachtingen acceptabel is.

Tot welke conclusie leidt nu de studie van Lucas?

1. Ten eerste geeft hij een theoretisch fundament aan Tinbergen's stelling ${ }^{13}$, dat de meeste beleidsvormen kwalitatief van aard zijn, in de zin: „A qualitative instrument (...) meaning, in mathematical language, that the type of certain structural relations existing before, is changed." Het betoog van Lucas betekent een grote stap in de richting van het operationeel maken van de beslissingstheorie bij onzekerheid en is hiermee een bevestiging van een voorspelling, die J. Drèze ${ }^{14}$ heeft gedaan in zijn rede op het wereldcongres van de Econometric Society, dat in 1970 te Cambridge gehouden werd. Wil men de gevolgen van een bepaald beleid met behulp van een model, waarin verwachtingsvariabelen voorkomen, bestuderen, dan dient in eerste plaats nagegaan te worden, in hoeverre door het beleid de structuur van het model veranderd wordt. Aan de hand van de nieuwe structuur kunnen dan de meetbare gevolgen van het gevoerde beleid worden berekend. De oorspronkelijke veronderstellingen zijn voldoende om de structuurveranderende invloed van het 
beleid vast te stellen. In die zin heeft Lucas een fundamentele bijdrage geleverd tot de theorie van de economische politiek. Zijn analyse verklaart, waarom econometrische modellen voorspelkracht bij gewijzigd beleid kunnen missen, een mogelijkheid, die, gelet op de wenselijkheid van goed economisch beleid, nader onderzocht moet worden.

2. Ten tweede illustreren de voorbeelden van Lucas een belangrijk en kenmerkend verschil tussen wiskundige modellen in de natuurwetenschappen en die in de economische en sociale wetenschappen. Chemische processen kunnen op grond van een modelsimulatie zonder terugkoppeling gestuurd worden en de verwachte uitkomsten bereikt. Toch leidt het voeren van maatschappelijk beleid - dikwijls al het aankondigen van maatregelen - tot kwantitatieve en kwalitatieve reacties. Het is zinvol rekening te houden met het feit, dat de gestuurde groep haar gedrag gaat afstemmen op het gekozen beleid. Een model, dat opgesteld is voor een periode met aanzienlijke stijgingen in de overheidsuitgaven, kan niet gewijzigd worden gebruikt voor een tijdvak met algemene bezuinigingen. Wel blijft het model geldig voor het doen van voorspellingen onder ongewijzigd beleid 15 .

In de econometrie zal het accent verlegd moeten worden van deterministische systemen, waarbij uiteindelijk een storingsterm wordt toegevoegd, naar stochastische modellen van menselijk gedrag in een wereld van onzekerheid. De deterministische aanpak kan, als cen eerste benadering, zinvol zijn, vooral voor het verkrijgen van een beter inzicht in het functioneren van de stochastische modellen. Maar deze aanpak kan ons blind maken voor belangrijke specifieke kenmerken van de stochastische modellen.

We hebben hier te maken met een vervanging van de in de econometrie gehanteerde wiskundige hulpmiddelen. Een yergelijkbaar verschijnsel heeft zich na de Tweede Wereldoorlog voorgedaan in de wiskundige economie. De theoretici zijn overgestapt van de in de fysica geliefde differentiaal- en integraalrekening naar de moderne en voor hun taken beter geschikte hulpmiddelen uil de maattheorie en de topologie ${ }^{16}$. Op grond van recente ontwikkelingen zou voorspeld kunnen worden dat de econometristen in de praktijk het pad van de deterministische systeemtheorie, die vooral was ontwikkeld ten behoeve van de natuurkunde, gaan verlaten, wat zij al gedeeltelijk in de theorie gedaan hebben. Naar mijn mening duiden deze nieuwe ontwikkelingen op het volwassen zijn van een vakgebied, dat ondanks zijn kort bestaan een respectabele ontwikkeling heeft doorgemaakt.

3. De veronderstelling van rationele verwachtingen bij consumenten en producenten in de economie is een eerste stap tot een realistische analyse van de economische beslissingen bij onzekerheid. Ten hoogste kan deze veronderstelling worden beschouwd als een eerste operationele aanzet tot de analyse van menselijk gedrag in een wereld van onzekerheid. Toch blijken de gevolgen van deze benadering dramatisch te zijn voor de traditionele beleidstheorie. Vanuit het standpunt van de economische theorie bezien is de veronderstelling van rationele verwachtingen bij onzekerheid onbevredigend, en zij zal dan ook niet de laatste wijsheid blijven, vooral nu de besliskunde bij onzekerheid in de zuivere economische theorie de kinderschoenen ontgroeid is. De bijdragen van Arrow ${ }^{17}$ en Drèze ${ }^{18}$ zijn mijlpalen op de weg naar een fundamenteler inzicht in de beslissingen bij onzekerheid. Een voorbeeld van toepassing van de theorie van rationeel gedrag bij onzekerheid is het in de beleggingsleer ontwikkelde „Capital Asset Pricing Model”, waarin naast de verwachte opbrengst van een belegging ook het verbonden risico in de beslissing wordt betrokken. In dit model wordt verondersteld dat verwachtingswaarde en standaard-deviatie van de opbrengst voor de belegger van belang zijn.

4. Uit de analyse van econometrische modellen met rationele verwachtingsvariabelen blijkt dat aandacht moet worden geschonken aan de processen van de exogene variabelen in het model 19 . Het is in de toegepaste econometrie gebruikelijk te veronderstellen dat de exogene variabelen gegeven zijn en geen verdere inspectie behoeven. Toch kunnen de meeste exogene variabelen verklaard worden met behulp van een model. Het meestal als exogeen beschouwde overheidsbeleid is bijv. gericht op het sturen van het conjunctuurverloop en laat zich dus verklaren uit de ontwikkeling van de conjunctuur. Kennis van het model, dat de exogene variabelen genereert, is nodig voor het formuleren van de rationele verwachtingen. Gezien de gevolgen van de hypothese van rationele verwachtingen bij beleidswijziging ligt het voor de hand, in de eerste fase van de modelbouw de exogene variabelen te analyseren met het oog op het vaststellen van beleidswijzigingen, vervolgens op grond daarvan de steekproef in beleidsregimes te splitsen om tenslotte voor elk regime de structuur van het model voor de endogene variabelen te bepalen. Dit leidt dan tot een uitbreiding van de modelbouwmethodologie. In de loop van een aan de Universiteit van Chicago verricht onderzoek zijn door A. Zellner en mij ${ }^{20}$ methoden ontwikkeld, waarmee onder meer het patroon van de exogene variabelen kan worden bestudeerd. Hoewel dit onderzoek werd verricht met het doel, de dynamische structuur van een econometrisch model empirisch te bepalen en te toetsen, vloeit uit de theorie van rationele verwachtingen een verdere toepassingsmogelijkheid van de door Zellner en mij gebruikte methoden voort. Tenslotte wil ik nog opmerken dat het statistische schatten ${ }^{21}$ van modellen met rationele verwachtingen in de laatste jaren veel bestudeerd is. Ik wil nu niet nader ingaan op deze onderwerpen, die een sterk technisch karakter dragen. 
Tot nu toe heb ik de gevolgen voor de theorie van de economische politiek vanuit de econometrische benadering van beslissingen bij onzekerheid belicht. De hypothese van de rationele verwachtingen en de veronderstelling daarbij, dat deze verwachtingen voldoende informatie over de toekomst inhouden, zijn beide maar een benadering van de werkelijkheid. Ik ben het eens met Prof. Merkies ${ }^{22}$, die vijf jaren geleden in zijn inaugurele rede zei: „De band met de werkelijkheid moet behouden blijven." Daarom kan dan ook, mede lettend op de ingrijpende gevolgen, die zij op de beleidsproblematiek heeft, de vraag gesteld worden, in hoevere de theorie van rationele verwachtingen realistisch is. Graag zou ik nu, waarde toehoorders, deze kwestie willen behandelen. Dan zal tevens duidelijk worden, dat de econometrie niet alleen methoden ter bestudering van economische modellen heeft ontwikkeld, maar ook, vooral in het laatste decennium, de theorievorming in de economische wetenschap heeft onderbouwd. De econometrie is een empirische wetenschap. Tot haar taken behoort het toetsen van conclusies uit de economische theorie.

\section{De empirische steun voor de hypothese van rationele verwachtingen}

De empirische inhoud van de beslissingsmodellen voor een wereld van onzekerheid is in de laatste jaren vooral op een bedrijfseconomisch gebied, nl. de beleggingsleer, onderzocht. Het onderzoek van E. F. Fama aan de Universiteit van Chicago diende als drijfveer voor de toetsing van hypothesen, bijv. die uit de efficiënte markt-theorie. Een overzicht van recent onderzoek op dit gebied wordt gegeven in zijn boek „Foundations of Finance"'23. Hoewel het niet mijn vakgebied is, heb ik toch - gedeeltelijk om wille van methodologische redenen - belangstelling voor de empirische benadering in de beleggingsleer. Misschien hebben de aanwezige bedrijfseconomen reeds al te lang moeten wachten op mijn gedachten over de toepassing van econometrische modellen in de be. drijfseconomie.

Ik wil natuurlijk niet zonder meer de econometrische methodologie aanprijzen. Maar toch levert de empirische aanpak in de beleggingsleer een voorbeeld op, van hoe het verzamelen van empirische bewijsstukken en het toetsen van hypothesen kunnen leiden tot een herziening van bestaande theorieën. Deze in de experimentele wetenschappen gebruikelijke werkwijze is van belang voor de economische wetenschap in het algemeen.

De efficiënte markt-theorie berust op twee veronderstellingen. De eerste is, dat op elk tijdstip de partijen in een bepaalde markt rationele verwachtingen aangaande de toekomstige prijsontwikkeling hebben; dat houdt in dat alle op dat moment voorhanden informatie over de toekomst verwerkt is in de prijsverwachting. De informatie is beschikbaar voor elke deelnemer aan de markt, die niet wordt beheerst door individuele participanten. Het leeraspect is dus belangrijk. De tweede veronderstelling is dat, voor zover het de toekomst betreft, alleen de prijsverwachtingen de huidige marktevenwichtsprijs beïnvloeden. Elke toets van de efficiënte markt-thcorie is een toets van deze twee veronderstellingen.

In modellen van de efficiënte markt is de toekomstige opbrengst van een belegging meestal niet gecorreleerd met de beschikbare informatie, die dan niet kan worden gebruikt ter verbetering van het rendement. De conclusie is in tegenspraak met de gebruikelijke, vooral in makelaarskringen heersende opvatting, dat de bestudering van de prijsevolutie in het verleden en van de economische ontwikkeling of van politieke gebeurtenissen een bruikbaar inzicht in het marktgebeuren zou kunnen geven, waardoor een hogere opbrengst voor een portefeuille verkregen kan worden. Daarbij is arbitrage tussen beleggingen en markten een noodzakelijke voorwaarde voor een efficiënte markt. Het is niet verbazingwekkend dat de efficiënte markt-theorie aanleiding heeft gegeven tot veel discussie en daarna tot een uitgebreide empirische toetsing van verschillende beleggingsstrategieën.

Hoewel de veronderstellingen van de efficiënte markt-theorie op het eerste gezicht niet realistisch lijken te zijn, spreken de uitkomsten van de statistische toetsen in het algemeen niet tegen deze theorie. Voor zover mij bekend is de beleggingsleer het onderdeel van de economische wetenschap, waarin het meeste empirische bewijsmateriaal is verzameld ten gunste van een hypothese, nl. de efficiënte markt-theorie met haar impliciete veronderstelling van rationele verwachtingen. De empirische studies beperken zich niet tot de aandelenmarkt. Onlangs is door Fama ${ }^{24}$ nagegaan, in hoeverre de prijsvariatie van Amerikaanse schatkistpapieren met een looptijd van één $\mathrm{t} / \mathrm{m}$ zes maanden de toekomstige korte termijn-rentevoet zou kunnen voorspellen. Zijn model gaat uit van de efficiënte markt-theorie. Naarmate rekening wordt gehouden met een premie voor het risico-verschil zijn de voorspellingen op grond van de prijsontwikkeling van schatkistpapieren even nauwkeurig als de voorspellingen op grond van de rentevoet in het verleden. Verder heeft Fama ${ }^{25}$ onderzocht of de korte termijn-rentevoet de toekomstige inflatievoet kan voorspellen. Het empirisch materiaal is ten gunste van de efficiënte markt-hypothese, die ook werd getoetst wat betreft de goederenmarkten, de wisselkoersen, enz. In de Vakgroep Kwantitatieve Methoden van onze Faculteit wordt onderzoek gedaan naar de prijsontwikkeling in de koffiemarkt. De eerste resultaten van de analyse van de clagelijkse loco- en termijnnoteringen van de koffieprijs aan de Londense beurs voor het jaar 1976/77 zijn aanmoedigend. Eruit blijkt dat de efficiënte markt-theorie een empirisch te funderen verklaring van de koffieprijsontwikkeling biedt. Enkele jaren geleden heb $\mathrm{ik}^{20}$ bij het 
analyseren van macro-economische en monetaire modellen uitkomsten verkregen, die de efficiënte markt-theorie ondersteunen. Zo bleek dat de maandelijkse wijziging van de Londonse Euro-dollar-rentevoet voor leningen van drie maanden in de jaren $1964 \mathrm{t} / \mathrm{m} 1974$ een niet-gecorreleerde reeks voorstelt. Dit resultaat kan verklaard worden vanuit een door arbitrage beheerste efficiënte markt.

Impliciet wordt in de zojuist besproken studies de veronderstelling van rationele verwachtingen getoetst. Gelet op de empirische steun voor een vereenvoudigde, a priori zelf onrealistische veronderstelling kan men zich echter afvragen, wat er aan de hand is. De conclusie kan evenwe niet luiden dat de hypothese van rationele verwachtingen een realistische benadering levert voor alle markten, vooral niet voor de geaggregeerde markten in macro-economische modellen. Ten minste nodigen de empirische resultaten uit de beleggingsleer en verwante vakgebieden uit tot nader onderzoek van de empirische inhoud van de rationele verwachtingen voor macro-economische variabelen, met name met het oog op het gebruik van het model voor beleidsproblemen. Variabelen, zoals een marktrentevoet of de verwachte inflatievoet, zijn belangrijk in een macro-economisch model. De voor deze variabelen verkregen empirische resultaten blijven zo geldig op macro-economisch niveau. Voor een aantal economische variabelen hebben we gegevens over de verwachte waarde, bijv. termijnnoteringen als verwachte waarde van toekomstige locoprijzen. Deze verwachtingsvariabelen kunnen in het model worden gebruikt. Wordt een verdeelde vertragingspecificatie voor de verwachtingsvariabelen in het model ingebracht, dan is er altijd nog de mogelijkheid, de resultaten van een modelsimulatie te vergelijken met de waargenomen verwachtingswaarden. Zo kan een aanwijzing over de kwaliteit van het model worden verkregen.

Voor andere macro-economische variabelen, bijv. de werkloosheid in de V.S., zijn modellen met rationele verwachtingen empirisch getoetst ${ }^{27}$ Deze modellen zijn meestal gebaseerd op M. Friedman's theorie van de natuurlijke werkloosheid28, waarin de eigenlijke werkloosheidsvoet evenredig met de voorspelfout van de inflatievoet afwijkt van de natuurlijke werkloosheidsvoet. De natuurlijke werkloosheid wordt bepaald door de fricties op de arbeidsmarkt en/of door onvolledige informatie in een evenwichtseconomie. Friedman's theorie levert een korte termijn Phillipscurve op. De conclusies uit de empirische toetsen zijn minder duidelijk dan die verkregen in de beleggingsleer. Het bij de empirische analyse van aandelen- en goederenmarkten verkregen optimisme is, wanneer hypothesen van rationeel gedrag bij onzekerheid worden getoetst op macro-economisch niveau, niet gerechtvaardigd. Belangrijke economische variabelen, zoals de werkloosheid, het nationaal produkt of de lonen en prijzen, zijn meestal sterk gecorreleerd denkt bijv. aan het conjunctuurverloop. In de laatste jaren heeft men zich ingespannen voor de ontwikkeling van modellen, waarin de waargenomen correlatie in economische reeksen wordt verklaard vanuit rationeel gedrag bij onzekerheid onder restricties, zoals vertragingen in de spreiding van informatie, institutionele remmingen, de afwezigheid van veilingen en volkomen markten, enz. De omvangrijke empirische steun voor de hypothese van rationeel gedrag bij onzekerheid heeft een sturende invloed uitgeoefend op het theoretisch onderzoek. In zijn overzichtsbijdrage „Rational Expectations in the Macro Model" bespreekt W. Poole ${ }^{29}$ de gevolgen van de efficiënte markt-theorie zonder en met institutionele en technische beperkingen voor macro-modellen. Volgens hem zijn theorieën, zoals die der rationele verwachtingen, niet afdoende verwerkt in het algemene macro-economische model. Al een aantal jaren is er in de V.S. theoretisch onderzoek op het gebied van contractuele prijs- en loontheorieën verricht met het doel, de institutionele aspecten van economische beslissingen en overeenkomsten te verklaren uit de theorie van rationeel gedrag bij onzekerheid. Zo wordt bijv. de gebruikelijke arbeidsovereenkomst in de vorm van vast loon onder meer verklaard vanuit de aversie tegen risico bij de werknemers en de kosten van het verzamelen van informatie. Deze theorieën, waaryan Poole ${ }^{\mathbf{3} 0}$ een overzicht geeft, zijn in mindere mate empirisch getoetst. Ze zouden kunnen leiden tot een ingrijpende herziening van de gangbare macroeconomische theorie en modellen. Ze lijken me vooral zinvol voor kleinere landen, waarvoor de veronderstelling van een volkomen markt niet van toepassing is.

\section{Enkele algemene conclusies}

Aan de hand van een paar studies over de theorie van rationeel gedrag in een wereld van onzekerheid heb ik gepoogd enige recente ontwikkelingen in mijn vakgebied te bespreken en hun betekenis voor beleid, voor het voorspellen en voor de toetsing van theorieën te illustreren. Andere niet minder belangrijke studies over bijv. de econometrie van onevenwichtsmarkten, de dynamische modellen in het algemeen, de problematiek van de causaliteit in een model, het empirisch onderzoek in de verschillende takken van de economische wetenschap, enz., zijn niet ter sprake gekomen, omdat ze in het korte tijdbestek van één openbare les niet genoegzaam behandeld kunnen worden. Maar de besproken voorbeelden maken duidelijk, hoe krachtig de conclusies kunnen zijn, die uit de theorie afgeleid en op empirisch onderzoek gefundeerd zijn. Daarbij blijft met K. Arrow te bedenken dat een theorie zonder empirische inhoud niet betrouwbaar, en empirisch onderzoek zonder theoretische achtergrond vruchteloos is ${ }^{31}$.

Gezien de smalle speelruimte voor elk overheidsbeleid, blijft het nog de vraag, in hoeverre beleidswijzigingen, die een aanzienlijke verandering 
van de modelstructuur teweegbrengen, mogelijk zijn. Toch is duidelijk geworden, in welke richting onderzoek kan - en naar mijn mening ook moet - verricht worden ten einde de kwaliteit van econometrische modellen te verhogen. In het verleden is de kwaliteit verhoogd door het inbrengen van de wederkerige afhankelijkheid in het model. Het is te verwachten dat een realistische aanpak van het onzekerheidsaspect ten aanzien van de gevolgen van iedere economische beslissing de modellen betrouwbaarder maakt. Maar zelfs dan kunnen geen nauwkeurige voorspellingen van beleidsinvloeden worden berekend. Er blijft altijd onzekerheid over de toekomst. Het doel van de modelbouwer kan dan ook niet de uitschakeling van de laatste onzekerheid zijn. Belangrijk voor de beoordeling van een model en de ermee gemaakte voorspellingen is de vraag, of de beschikbare informatie en kennis verstandig worden gebruikt. Dat ik vandaag de hoofdprijs in de loterij win, betekent nog niet dat het kopen van een lot ex ante verstandig was.

Hoe meer inzicht in de beslissingen bij onzekerheid en in de informatieverwerking wordt verkregen, des te belangrijker dit inzicht voor de ondersteuning van beslissingen wordt. Het feit, dat anderen een model gebruiken, dwingt mijzelf tot een dergelijke handelswijze. Zo kan een theorie met normatieve inhoud uiteindelijk een positieve theorie worden, een theorie, die een stuk werkelijkheid verklaart. En daardoor zelfs kunnen de huidige theorieën van rationeel gedrag bij onzekerheid, die in het verleden niet bevestigd konden worden, in de toekomst inhoud krijgen.

De in deze les besproken econometrische studies zouden niet mogelijk zijn geweest zonder de belangrijke ontwikkelingen op het gebied van de statistische analyse van tijdreeksen, een jong veld van onderzoek in de statistiek. De uitspraken van de theorie van rationeel gedrag bij onzekerheid betreffen de snelheid, waarmee mensen op nieuwe gebeurtenissen reageren. Behalve dan voornamelijk technische en institutionele remmende factoren zijn er, aldus deze theorie, geen langdurige vertragingen op grond van psychologische factoren te verwachten. Rationeel gedrag bij onzekerheid leidt tot restricties voor de tijdscorrelatie of de dynamische structuur van economische reeksen. Voor het statistisch toetsen van deze restricties levert de tijdreeksanalyse geschikte middelen. Het toepassen van tijdreeksmethoden in de econometrie is meer dan een modeverschijnsel. De verrijking van de econometrie met methoden uit de tijdreeksanalyse en het belang van nieuwe ontwikkelingen in de econometrie voor economisch beleid en theorievorming in de economie hoop ik $U$ in dit betoog duidelijk gemaakt te hebben. De omgekeerde stelling zou gemakkelijk aangetoond kunnen worden. Maar dit wil ik als huiswerk aan geïnteresseercle toehoorders overlaten.

Aan het slot van mijn betoog gekomen wil ik graag mijn dank uitspreken aan het Bestuur van de Vereniging voor Wetenschappelijk On- derwijs op Gereformeerde Grondslag en aan het Bestuur van de Vrije Universiteit voor mijn benoeming. Het Bestuur van de Vereniging heeft het risico niet geschuwd een jonge buitenlander een verantwoordelijke taak toe te vertrouwen. Ik hoop dat ik het in mij gestelde vertrouwen zal rechtvaardigen.

Geachte Collegae van de Economische Faculteit en in het bijzonder die der Vakgroep Kwantitatieve Methoden, ik dank U hartelijk voor de vriendelijke opname in Uw kringen.

Dames en Heren studenten, ik koester de hoop dat in de toekomst onze samenwerking even vruchtbaar zal zijn als in het nabije verleden.

Waarde toehoorders, ik dank U voor Uw aandacht.

NOTEN:

1. Walras, L., Eléments d'économie politique pure, Lausanne, F. Rouge, 1900.

2. Zie blz. 21 van Vermaat, A. J., Over de wiskunde in de economie. Openbare les V.U. Amsterdam 1970, Haarlem, De Erven F. Bohn N.V., 1970.

3. Kirschenmann, P. P., Exactness. Inaugurele rede V.U. Amsterdam 1977, Amsterdam, V.U., 1977.

4. Theil, H., Optimal decision rules for government and industry, Amsterdam, North-Holland Publ. Co., 1964.

5. Zie blz. 68 van Tinbergen, J., On the theory of economic policy, Amsterdam, North-Holland Publ. Co., 1966, 4th edit.

6. Lucas, R. E., 'Econometric policy evaluation: a critique', in Brunner, K., and A. H. Meltzer (eds.), The Phillips curve and labor markets, vol. 1 of the Carnegie-Rochester Conferences on Public Policy, Amsterdam, North-Holland Publ. Co., 1976, 19-46.

7. Koyck, L. M., Distributed lags and investment analysis, vol. IV of Contributions to Economic Analysis, Amsterdam, North-Holland Publ. Co., 1954.

8. Muth, J. F., 'Optimal properties of exponentially weighted forecasts', Journal of the American Statistical Association, 55, 1960, 299-306; Muth, J. F., 'Rational expectations and the theory of price movements', Econometrica, 29, 1961, 315-335.

9. Savage, L. J., The foundations of statistics, New York, John Wiley and Sons, 1954.

10. Arrow, K. J., 'Le rôle des valeurs boursières pour la répartition la meilleure des risques', Econométrie, CNRS, Paris 1953, 41-47. Engelse vertaling: 'The role of securities in the optimal allocation of risk bearing', Review of Economic Studies, 31, 1964, 91-96. 
11. Debreu, G., Theory of value, New York, J. Wiley and Sons, 1959.

12. Het is de omgekeerde stelling van: Merkies, A. H. Q. M., Van prognoses naar programma's. Inaugurele rede V.U. Amsterdam 1973, in Intermediair, 17,4 mei $1973,7-12$.

13. Op. cit., blz. 71.

14. Drèze, J. H., 'Econometrics and decision theory', Econometrica, 40, 1972, 1-17, zie blz. 16; ook in Fienberg, S. E., and A. Zellner (eds.), Studies in Bayesian Econometrics and Statistics, Amsterdam, North-Holland Publ. Co., 1974, 17-38, zie blz. 36 .

15. Zie Gordon, R. J., 'Can econometric policy evaluations be salvaged? - A comment', in Brunner, K., and A. H. Meltzer (eds.), op. cit., 47-61.

16. Zie Koopmans, T. C., Three essays on the state of economic science, New York, McGraw-Hill Co., 1957.

17. Op. cit.

18. Drèze, J. H., (ed.), Allocation under uncertainty: equilibrium and optimality, New York, McMillan, 1974.

19. Zie Wallis, K. F., Econometric implications of the rational expectations hypothesis, paper presented to the Econometric Society European Meeting, Vienna, 1977 (ongepubliceerd).

20. Zellner, A., and F. Palm, 'Time series analysis and simultaneous equation econometric models', Journal of Econometrics, 2, 1974, 17-54;

Zellner, $\mathrm{A}$, and $\mathrm{F}$. Palm, 'Time series and structural analysis of monetary models of the US. economy', Sankhyã The Indian Joumal of Statistics, C. 37, 1975, 12-56.

21. Zie bijv.: Mc Callum, B. T., 'Rational expectations and the estimation of econometric models: an alternative procedure', International Economic Review, 17, 1976, 484-490;

Nclson, C. R., 'Rational expectations and the estimation of econometric models', International Economic Review, 16, 1975, 555-561; Wallis, K. F., op. cit.

22. Merkies, A. H. Q. M., op. cit., blz. 9.

23. Fama, E. F., Foundations of finance, New York, Basic Books Inc., 1976.

24. Fama, E. F., 'Forward rates as predictors of future spot rates', Journal of Financial Economics, 3, 1976, 361-377.

25. Fama, E. F., 'Short-term interest rates as predictors of inflation', American Economic Review, 65, 1975, 269-282.

26. Palm, F., 'Testing the dynamic specification of an econometric model with an application to Belgian data, European Economic Review, 8, 1976, $269-289$.

27. Voor een overzicht van verschenen resultaten, zie blz. 13-14 van Shiller R. J., 'Rational expectations and the dynamic structure of macro-economic models: a critical review', Journal of Monetary Economics, 4, 1978, 1-44.

28. Friedman, M., 'The role of monetary policy', American Economic Review, $58,1968,1-17$

29. Poole, W., 'Rational expectations in the macro model, (with comments and discussions)', Brookings Papers on Economic Activity, 2, 1976, 463-514.

30. Zic Poole, op. cit.

31. Zie blz. 132 van Arrow, K. J., 'Mathematical models in the social sciences' in Lasswell, H. D., and D. T. Lerner (eds.), The policy sciences: recent developments in scope and method, Stanford, Stanford University Press, 1951, 129-154. 